\title{
Fertility Transition through Four Generations and Determinants of Third Birth in Manipur
}

\author{
1 Dillip C Nath, ${ }^{2}$ N. Sharat Singh, ${ }^{3}$ H. Brojeshwor Singh \\ ${ }^{1}$ Professor in Statistics, Gauhati University, Gauhati \\ ${ }^{2}$ Asst. Professor in Statistics, Thoubal College under Manipur University, Imphal \\ ${ }^{3}$ Research Scholar, Dept. of Statistics, Gauhati University, Gauhati
}

\begin{abstract}
A cross sectional as well as community based study was conducted taking 1296 currently married women through cluster sampling scheme in the rural areas of four valley districts of Manipur. The fertility of generation-4 that is 3.59 is transited from the generation-1 (4.78), generation-2 (4.83), and generation-3 (5.69). Utilizing multiple and logistic regression models, the determinants of completed fertility of the last generation-4 are detected to be age at marriage $(P<0.01)$, son preference $(P<0.05)$, contraceptives uses $(P<0.05)$, Islam religion $(P<0.01)$, educational level $(P<0.01)$. The findings may be a baseline information in community fertility indices.
\end{abstract}

Key words: generation fertility, son preference, clan, $3^{\text {rd }}$ birth transition, odds ratios

\section{Introduction}

India's National Population Policy (NPP) - 2000 had formulated the short, medium and long term objectives of the policy to materialize the international agenda from a sole concern with fertility reduction. While the medium-term objective is to bring the total fertility rate to replacement level (2.1) by 2010, the longterm objective is to achieve a stable population by 2045 , at a level consistent with the requirements of sustainable economic growth, social development, and environmental protection. The failure on short or medium-run goal would have serious implication for the long-run objective of population stabilization. Further, recognizing the importance of health in the process of economic and social development and improving the quality of life of citizens, India's National Rural Health Mission: 2005-12 within the framework of Millennium Development Goals (MDG) also emphasises in its goals on population stabilization, gender and demographic balance.

With a little deviation from $22 \%$ in $1992-93$ to $25 \%$ in 1998-99, National Family Health Survey (NFHS) reports the significant inter-state variations in the unwanted fertility in India and unplanned pregnancies are still relatively common. However, unwanted fertility as percent of TFR declined in the low fertility southern states of Kerala, Tamil Nadu and Andhra Pradesh and rise up in most of the high fertility states like Bihar, Rajasthan, Uttar Pradesh, Madhya Pradesh, and Orissa over the same period. If the unwanted fertility component is taken care of or gets eliminated then the TFR would come down to replacement level of 2.1 or even below that in most parts of India. The NFHS-3 report also stresses that if all women were to have only the number of children they wanted, the TFR would be 1.9 instead of 2.7. Among the births in the five years before the survey, $10 \%$ were wanted later and $11 \%$ were not wanted. In the report, $71 \%$ of adults want no more children, are already themselves sterilized, or have a spouse who is sterilized. Among those who do want another child, about half would like to want at least two children. Two-thirds of women and men consider the ideal family size to be 2 children or less. This behavioural disparity is in complex fashion in Manipur. But the identification of factors determining the complexities of fertility differential has immense value on its transition pattern through some past generations and hence the present study has been initiated. Despite, no community based study has so far been conducted in Manipur particularly in rural areas where 'natural fertility' (Henry, 1961) seems to be existed. Thus, it is to investigate the socio-demographic determinants of fertility differential and the third birth transition.

\section{Literature Review}

Many past studies highlighted that high fertility is highly influenced by unwanted pregnancies due to unmet need of the contraceptives (Adeyemi et al., 2005; Calle et al., 2006; Blanc et al., 2009). When the fertility declines a relatively greater demand for sons than daughters is noticed in developing India and it is not generally considered in industrial societies. Analyzing the data from the United States, Pollard and Morgan (2002) find an evidence of preference for a balance family with at least one son and one daughter. Hank and Kohler (2000) support the balance family in many European countries. But they also find some countries with a girl preference. In Denmark say for instance, there is a preference for balanced composition of sex, but also a mild girl 
preference in the families (Jacobsen et al. 1999). In many developing countries, reproductive intentions and behaviours are strongly influenced by sex of surviving children (Arnold, 1997; Hussain et al. 2000; Youssef, 2005; Khawaja and Randall, 2006). Utilizing Demographic and Health Survey (DHS) data from fifty-seven countries, Arnold (1997) empirically shows that son preference exists particularly strong in Southern Asian Countries. Women's contraceptive use and duration of last birth interval are also linked to stopping childbearing after the birth of a son in Nepal (Leone et al., 2003).

Most of the Indian couples have thus a strong preference for sons over daughters. Through the past studies three major factors have been identified that underlie such socio-demographic phenomenon in India. They are economic, socio-cultural and religious utilities. Sons are more likely than daughters to provide family labour on the farm or in family business and support their parents of old age, although there is some recognition that sons are no longer a dependable source of old age support (Nath and Deka, 2004). A son brings upon marriage a daughter-in-law into his family and she provides additional help around the house as well as an economic reward in the form of dowry payments. In the context of India's patriarchal family system, having one son is imperative for continuation of the family line, and many sons provide additional status to the family. The utility of having sons also arises from the important religious functions that only sons can provide. In an effort to have sons, many couples continue to have children after achieving their desire family size. In case of intention, about $20 \%$ of Indian couples want more sons than daughters, but only 2 to $3 \%$ of them want more daughters than sons (IIPS, 2007). In Manipur, 31.2\% of ever married women who want more sons than daughters according to NFHS-3:2005-06 which is declining from that of 36.5\% in NFHS-2:1998-99 and 43.4\% in NFHS-1:1992-93 (IIPS, 2008).

\section{Objectives:}

The present study is to check the pattern of fertility transition for the last four patrilineal generations and to explore the determinants of the current fertility dynamics. Also it is to investigate the significant factors for third birth transition in Manipur.

\section{Materials And Methods}

A cross sectional study of 1296 currently married women was conducted through a cluster sampling scheme in rural community of four valley districts of Manipur, a state of Indian border with Myanmar (Bishnupur, Imphal East, Imphal West and Thoubal) during the period from the $27^{\text {th }}$ April, 2009 to December 2010 taking the $27^{\text {th }}$ April 2009 as reference date. The cluster with rural-urban differential is defined according to Population of Manipur (Directorate of Economics \& Statistics, 2008). Processing the empirical data through SPSS, multiple regression and logistic regression analysis are adopted in addition to the classical statistical tests. Here, the response variable 'fertility' is defined as number of children ever born to a mother and the 'third birth transition' is quantified by the issue of third live birth. Sex preference may be measured in two ways (Gray and Evans, 2004). Firstly, by examining 'intention data' which focuses on the respondent's sex preference of future births and secondly by examining 'behavioural data' which investigates respondent's fertility behaviour given the sex of existing children. The intention data is situation dependent (Marleau and Saucier, 2002). Behavioural data reveals actual preferences in that progression from at least one to higher parity based on existing children. However, this method cannot be used to look at sex preference of an only or first child (Goodkind, 1999). The present article also focuses the effect of sex preference on fertility level using intention data which is measured by the couple's desire number of son. In case of generation (patrilineal), fertility of $4^{\text {th }}$ generation is defined by the number of live births of the present couples (self). The fertility of $3^{\text {rd }}$ generation is quantified by the number of offspring of the husband's father that is the number of brother and sisters of husband. And that of $2^{\text {nd }}$ and $1^{\text {st }}$ generations are the number of brother and sister of husband's father and husband's grandfather (husband father's father). The $4^{\text {th }}$ generation fertility is computed from eligible women of age 40 years and above so that the fertility level may be assumed to be completed one. Fertility levels of past generations are retrospectively noted at the time of survey.

\section{Analysis and Results}

In the population, the completed fertility of the present couples is observed to be $3.59 \pm 1.57$ which is

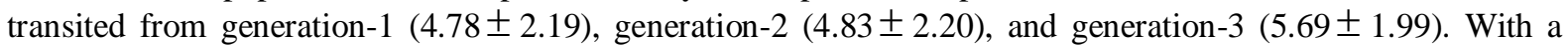
maximum of more than 6 children for Muslim women followed by Christian and others with 4.33 children and the minimum level of 3.5 children the present completed fertility level is significantly varied $(\mathrm{F}=9.88, \mathrm{P}<0.01)$ with respect to religious differential. However, the fertility for the past three generations is observed to be insignificantly different with religion in the sense that fertility levels for past three generations are equivalently high. The fertility levels are noted to be insignificantly varied with different seven clans - Mangang, Luwang, Khuman, Moirang, Angom, Kha-Nganba, Sarang-Leisangthem and others (no clan thereof) for the last three generations. But the fertility of $1^{\text {st }}$ generation is found to be significant according to clan $(\mathrm{P}<0.01)$. Also 
Couple's desire number of son significantly influences $1^{\text {st }}$ and $4^{\text {th }}$ generations fertility irrespective of the joint effects of other factors under analysis.

In multivariate analysis of the present fertility level, the two response outcome variables are taken -i) fertility which is defined as the actual number of live birth and ii) third birth transition as quantified to be 1 , if the mother has at least third live birth and 0 , otherwise. Utilising binary $(0,1)$ dummy variable technique, the explanatory variables considered are religion ( 1 if case and 0 , otherwise i,e joint), type of family ( 1 if nuclear and 0 otherwise), educational level, employment status ( 1 if employed in Govt./public sectors having good regular income and 0 otherwise - unemployed), generation's fertility, age at marriage, duration of marriage, couple's desire number of son, and use of contraceptives ( 1 if used effectively and 0 otherwise) during transition of third birth. The educational level is measured by the number of completed academic years in education. The inclusion of explanatory variables in the regression models is performed subject to the scanning of multicollinearity (Rethrford and Choe, 1993) with cutoff-zero order correlation of 0.3.

Considering 1296 currently married women a regression analysis is performed on the current fertility with respect to fourteen classified explanatory variables of interest. Only four variables are identified to have their significant influences on the fertility differentials. They are duration of marriage $(\mathrm{P}<0.001)$, use of contraceptives during the transition of third birth $(\mathrm{P}<0.05)$, couple's desire number of son $(\mathrm{P}<0.01)$ and the Islam religion $(\mathrm{P}<0.001)$ shown in table-2. Each influential factor is observed their level of significance after adjusted the joint effects of other variables under analysis. The results are detected by the multiple regression model having its diagnostics $-\mathrm{R}^{2}=70.5 \%, \mathrm{~F}=68.74, \mathrm{P}<0.001$, Durbin-Watson $(\mathrm{D})=1.97$. Under stepwise method, the elsewhere four variables can be signified to be determinants of fertility indices (table-2a). The levels of significance and the directions of influence are also found to be similar in nature. But, the values of regression coefficients observed in the later model are somewhat different from the previous model owing to its model summary viz., $\mathrm{R}^{2}=70.2 \%, \mathrm{~F}=242.58, \mathrm{P}<0.001, \mathrm{D}=1.94$. As such, the four variables can explain at least seventy percent of total variation on the current fertility in rural valley areas of Manipur.

More precisely, a binary logistic regression analysis on the transition of third birth (1if at least $3^{\text {rd }}$ birth occurred, 0 otherwise) is again carried out to verify the influencing factors of third birth that could not join the national goal of replacement level (2.1). Here, six determinants out of thirteen factors can be identified in both adjusted and stepwise methods shown in table-3. However, the results are observed with little varied significance levels and odds ratios (OR) in the two models. The significant factors found in the last model are fertility of generation-3 $(\mathrm{P}<0.05$, OR=1.17 with $95 \% \mathrm{CI}: 1.03-1.33)$, fertility of generation-2 $(\mathrm{P}<0.05, \mathrm{OR}=0.87$ with 95\%CI: 0.78-0.97), educational level of wife ( $\mathrm{P}<0.01, \mathrm{OR}=0.87$ with 95\%CI: 0.82-0.92), age at marriage of wife ( $\mathrm{P}<0.01$, OR=0.87 with 95\%CI: 0.82-0.92), use of contraceptives $(\mathrm{P}<0.05$, OR=0.23 with 95\%CI: 0.08 $0.71)$ and employment of husband $(\mathrm{P}<0.05, \mathrm{OR}=1.88$ with $95 \% \mathrm{CI}: 1.13-3.12)$ elicited in table-3a.

\section{Discussion}

Four determinants of fertility differential that duration of marriage, Islam religion, contraceptive uses and couple's desire number of son fit the last regression model. While the duration of marriage is demographic factor which can not be managed by couple after marriage, religion the social factor can not be controlled by individual level too. The duration of marriage is transformed from mother's age at marriage. Bavel (2003) also observed that for many pre-industrial populations that the duration of marriage influences age specific marital fertility. But, the reason remains unclear. The possible reasons are given by past findings of Kirdar et al. (2009) and Lieberman (2009). They stressed in their findings that the age at first association of younger partner in early marriage predicts fertility is that co-residence duration or duration of marriage serves as a cue to siblingship mainly for younger partner; older partners use a different kinship cue not influenced by durations of association. While adjusted the joint effects of three other variables in the last regression model, Islam religion is observed to be high influential factor $(\mathrm{P}<0.001)$ leading to high fertility. It may be the fact that generally Muslim women are low educated, having low income, taking early marriage and hence resulting high fertility. Many past findings emphasized that Muslim religious doctrine does not specially prohibit voluntary birth limitation, the institutional pressures to have many children, especially sons, are strong. It is again supported by Singh et al. (2007).

Among the two behavioural factors - desire number of son $(B=0.152, P<0.01)$ has more influential on high fertility than use of contraceptives which can reduce the current fertility $(B=-0.463, P<0.05)$. It may be interpreted as couple's desire of one more son gives an increase of 0.15 in current fertility level with $95 \% \mathrm{CI}$ : 0.06-0.25. The finding is in agreement with some other past findings. In many developing countries, reproductive intentions and behaviours are strongly influenced by sex of surviving children (Hussain et al. 2000; Youssef, 2005; Khawaja and Randall, 2006; IIPS, 2007). This ill behave may have retarded India's fertility decline and therefore the present fertility level is far behind the national socio-demographic goals to be achieved by 2010 according to National Population Policy 2000. Educational levels, age at marriage and use of contraceptives have also negatively significant impacts on third birth transition for many reasons. It is witnessed in the logistic regression analysis. The significance of the factors may be interpreted as similar in the case of multiple regression analysis. Keeping constant the joint effects of education and age at marriage of wife, 


\section{Fertility Transition Through Four Generations And Determinants Of Third Birth In Manipur}

husband's employment status and contraceptive use, the fertility of generation-3 directly influences the third birth and that of generation-2 has negative influence on the phenomenon of third birth transition in rural Manipur. It seems that the current fertility level could significantly be reduced by the influence of generation-2 (husband's father).

\section{Acknowledgement}

The authors are indebted to University Grants Commission (India) for financial assistance for the present data with reference to its sanction No. F. 5-331/2009-10(MRP/NERO)/5808 dt. $14^{\text {th }}$ Dec. 2009.

\section{References}

[1]. 'Adeyemi, A. B., Ijadunola, K. T., Orji, E. O., Kuti, O. and Alabi, M. M.,2005, The Unmet need for contraception among Nigerian women in the first year post-partum. European Journal of Contraceptive Reproductive Health Care; 10 (4): 229-34.

[2]. Arnold, F. R., 1997, Gender preference for children: Findings from Demographic and Health Surveys. Paper presented at the 23rd General Population Conference of the International Union for the Scientific Study of Population (IUSSP), Beijing, October. 11-17.

[3]. Blanc, A. K., Tsui, A. O., Croft, T. N. and Trevit, J. L., 2009, Patterns and trends in adolescent' contraceptive use and discontinuation in developing countries and comparisons with adult women. International Perspectives on Sexual and Reproductive Health, 35(2): 63-71.

[4]. Bavel, J. V., 2003, Does an effect of marriage duration on pre-transition fertility signal parity-dependent control? An empirical test in 19th century Leuven, Belgium, Population Studies, 57(1): 55-62.

[5]. Calle, M., Rodrigues, R. N. and Leite, I. C., 2006, Unmet needs for contraceptive methods in Bolivia, Cad Saude Publication, 22(9): 1989-96.

[6]. Directorate of Economics and Statistics, 2008, Population of Manipur - 2006. Government of Manipur.

[7]. Goodkind, D., 1999, Should parental sex selection be restricted? Ethical questions and their implications for research and policy. Population Studies, 53: 49-61.

[8]. Gray, E. and Evans, A., 2004, Parity progression in Australia: what role does sex of existing children play? Paper presented at 12th Biennial Conference on population and society: issues, research, policy held on 15-17 September, in Canberra, Australia

[9]. Hank, K. and Kohlar, H. P., 2000, Gender preferences for children in Europe: empirical results from 17 FFS Countries. Demographic Research, 2: 256-261.

[10]. Henry, L., 1961, Some data on natural fertility. Eugenics Quarterly, 8:81-91.

[11]. Hussain, R., Fikree, F. F. and Berendes, H. W., 2000, The role of son preference in reproductive behavior in Pakistan. Bulletin of the World Health Organisation, 78(3): 379-388.

[12]. International Institute for Population Sciences (IIPS), 2007, National Family Health Survey-3, 2005-06: Key findings: 5.

[13]. International Institute for Population Sciences (IIPS). National Family Health Survey-3, 2005-06: Manipur 2008: 46.

[14]. Jacobsen, R., Mollar, H. and Engholm, G., 1999, Fertility rates in Denmark in relation to the sexes of preceding children in the family. Human Reproduction, 14: 1127-1130.

[15]. Kirdar, M. G. and Dayıglu, M. K., 2009, The impact of schooling on the timing of marriage and fertility: evidence from a change in compulsory schooling law. Assessed as mpra.ub.uni-muenchen.de/13410 dated 25/ 09/09.

[16]. Khawaja, M. and Randall, A., 2006, Intifada Palestinian fertility and women's education. Genus, LXII(1): 21-51.

[17]. Lieberman, D., 2009, Rethinking the Taiwanese minor marriage data: evidence the mind uses multiple kinship cues to regulate inbreeding avoidance. Evolution and Human Behavior, 30(3): 153-160.

[18]. Leone, T., Matthews, J. and Zuanna, G. D., 2003, Impact and determinants of sex preference in Nepal. International Family Planning Perspectives, 29(2): 69-75.

[19]. Marleau, J. D. and Saucier, J. F., 2002, Preference for a first-born boy in Western Societies. Journal of Biosocial Sciences, 34: 1327.

[20]. Nath, D. C. and Deka, A. K., 2004, The importance of son in a traditional society: how elderly parents see it? Demography India, 33(1): $33-46$.

[21]. Pollard, M. S. and Morgan, S. P., 2002, Emerging parental gender indifference? Sex composition of children and the third birth. American Sociological Review, 67: 600-613.

[22]. Singh, N. S., Narendra, R. K. and Hemochandra, L., 2007, Determinants of waiting time to conception in Manipuri women. Kuwait Medical Journal, 39(1): 39-43.

[23]. Youssef RM. Duration and determinants of inter birth interval: community-based survey of women in southern Jordan. Eastern Mediterranean Health Journal, 2005. 11(4): 559-572.

Table -1: Fertility transition by generations

\begin{tabular}{|c|c|c|c|c|c|c|c|c|c|}
\hline \multirow{2}{*}{\multicolumn{2}{|c|}{ Variable }} & \multicolumn{8}{|c|}{ Fertility Transition } \\
\hline & & \multicolumn{2}{|c|}{$\begin{array}{l}\text { Generation-4 } \\
(n=437 ; \\
\text { maternal } \\
\text { age>40yr })\end{array}$} & \multicolumn{2}{|l|}{$\begin{array}{l}\text { Generation-3 } \\
(n=1296)\end{array}$} & \multicolumn{2}{|l|}{$\begin{array}{l}\text { Generation-2 } \\
(n=1296)\end{array}$} & \multicolumn{2}{|c|}{$\begin{array}{l}\text { Generation-1 } \\
\left(\mathrm{n}=719 ; 417^{\mathrm{p}}\right. \\
\left.302^{\mathrm{m}}\right)\end{array}$} \\
\hline \multirow[t]{2}{*}{ All } & $\begin{array}{l}\mathrm{P} \\
\text { Patrilineal }\end{array}$ & \multirow{2}{*}{\multicolumn{2}{|c|}{$3.59 \pm 1.569$}} & \multicolumn{2}{|l|}{$5.69 \pm 1.987$} & \multicolumn{2}{|l|}{$4.83 \pm 2.203$} & \multicolumn{2}{|l|}{$4.78 \pm 2.188$} \\
\hline & Matrilinea & & & \multicolumn{2}{|l|}{$5.58 \pm 1.917$} & \multicolumn{2}{|l|}{$4.94 \pm 2.187$} & \multicolumn{2}{|l|}{$4.20 \pm 1.874$} \\
\hline $\begin{array}{l}\text { Religio } \\
\mathrm{n}\end{array}$ & Hindu & $\begin{array}{l}3.50 \pm 1.54 \\
4 \\
(360)\end{array}$ & $\begin{array}{l}2 \\
\infty \\
\infty \\
11 \\
11\end{array}$ & $\begin{array}{l}5.5 .69 \pm 2.00 \\
2 \\
(1103)\end{array}$ & $\stackrel{m}{=}$ & $\begin{array}{l}4.78 \pm 2.202 \\
(1103)\end{array}$ & $\begin{array}{l}m \\
m \\
\infty \\
\\
\text { II }\end{array}$ & $\begin{array}{l}4.79 \pm 2.24 \\
1 \\
(360)\end{array}$ & ơ \\
\hline
\end{tabular}


Fertility Transition Through Four Generations And Determinants Of Third Birth In Manipur

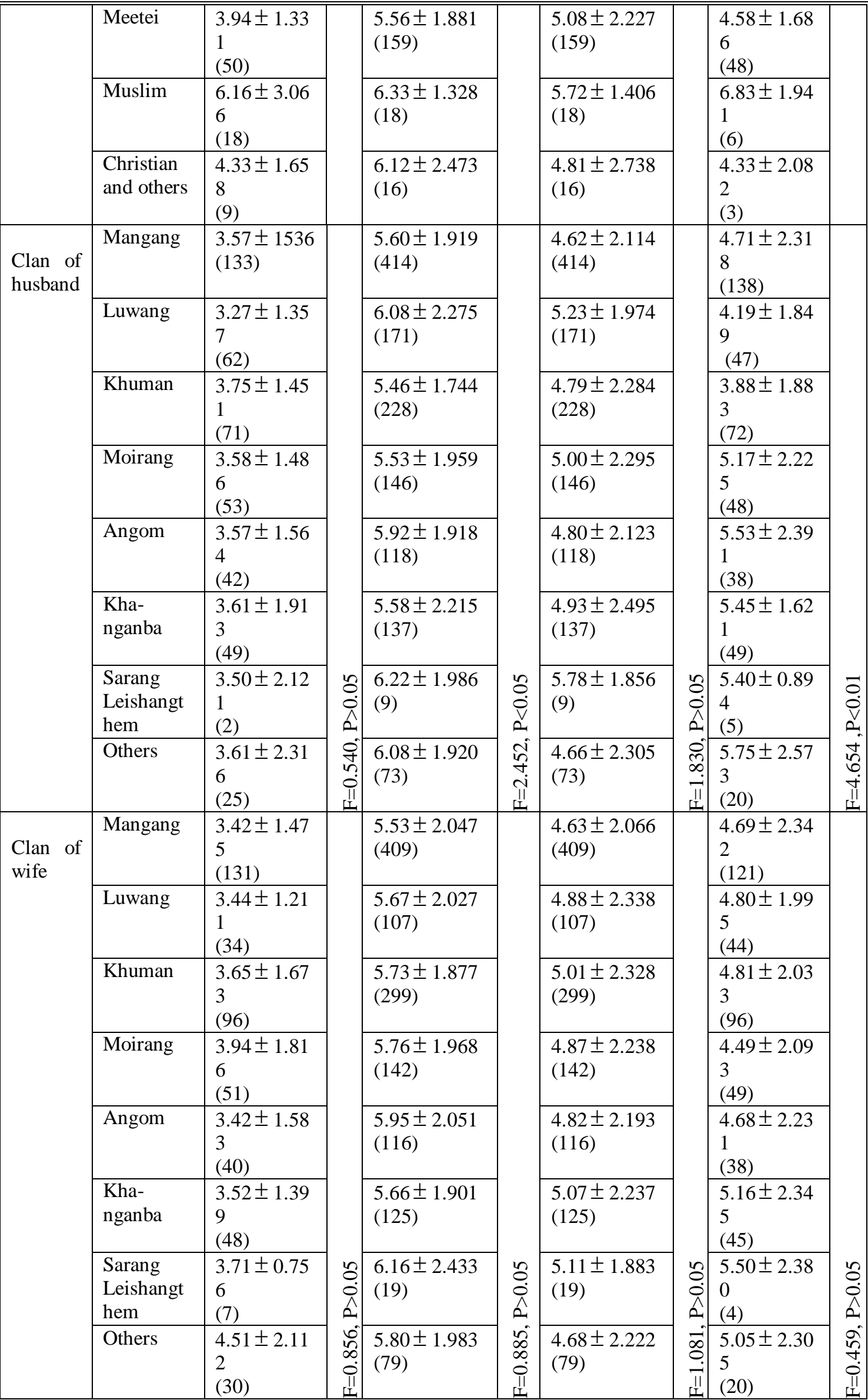


Fertility Transition Through Four Generations And Determinants Of Third Birth In Manipur

\begin{tabular}{|c|c|c|c|c|c|c|c|c|c|}
\hline \multirow{4}{*}{$\begin{array}{l}\text { Couple' } \\
\text { s desire } \\
\text { no. of } \\
\text { sons }\end{array}$} & $\bar{~} 1$ & $\begin{array}{l}2.39 \pm 1.38 \\
0 \\
(84)\end{array}$ & \multirow{4}{*}{$\begin{array}{l}0 \\
0 \\
v \\
0 \\
0 \\
0 \\
0 \\
0 \\
0 \\
0\end{array}$} & $\begin{array}{l}5.64 \pm 2.020 \\
(322)\end{array}$ & \multirow{4}{*}{ 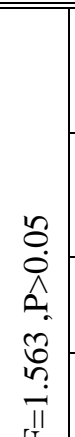 } & $\begin{array}{l}4.82 \pm 2.249 \\
(322)\end{array}$ & \multirow{4}{*}{ 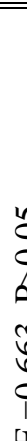 } & $\begin{array}{l}5.08 \pm 2.21 \\
0 \\
(110)\end{array}$ & \\
\hline & 2 & $\begin{array}{l}3.59 \pm 1.30 \\
5 \\
(227)\end{array}$ & & $\begin{array}{l}5.68 \pm 1.948 \\
(640)\end{array}$ & & $\begin{array}{l}4.79 \pm 2.184 \\
(640)\end{array}$ & & $\begin{array}{l}4.82 \pm 2.11 \\
9 \\
(200)\end{array}$ & $\underline{s}$ \\
\hline & 3 & $\begin{array}{l}4.13 \pm 1.42 \\
6(100)\end{array}$ & & $\begin{array}{l}5.63 \pm 1.935 \\
(271)\end{array}$ & & $\begin{array}{l}4.99 \pm 2.159 \\
(271)\end{array}$ & & $\begin{array}{l}4.25 \pm 2.12 \\
7(91)\end{array}$ & v \\
\hline & $4+$ & $\begin{array}{l}5.59 \pm 2.71 \\
(26)\end{array}$ & & $\begin{array}{l}6.21 \pm 2.363 \\
(63)\end{array}$ & & $\begin{array}{l}4.68 \pm 2.422 \\
(63)\end{array}$ & & $\begin{array}{l}5.198 \pm 2.8 \\
34(16)\end{array}$ & तi \\
\hline
\end{tabular}

Table-2a: Stepwise regression coefficients on current fertility

\begin{tabular}{|c|c|c|c|c|c|c|c|c|}
\hline \multirow{2}{*}{$\begin{array}{l}\text { Mod } \\
\text { el }\end{array}$} & \multirow{2}{*}{ Variable } & \multicolumn{2}{|c|}{$\begin{array}{l}\text { Unstandardized } \\
\text { coefficient }\end{array}$} & \multirow{2}{*}{$\begin{array}{l}\begin{array}{l}\text { Standar } \\
\text { dized } \\
\text { coeffici } \\
\text { ent }\end{array} \\
\beta\end{array}$} & \multirow[t]{2}{*}{$\mathrm{t}$} & \multirow[t]{2}{*}{$\mathrm{P}$} & \multicolumn{2}{|c|}{$95 \% \mathrm{CI}$ for $\mathrm{B}$} \\
\hline & & B & $\mathrm{SE}$ & & & & Lower & Upper \\
\hline \multirow[b]{2}{*}{1} & (Constant) & .742 & .062 & & 11.974 & .000 & .620 & .864 \\
\hline & $\begin{array}{l}\text { Duration of } \\
\text { marriage }\end{array}$ & .135 & .005 & .808 & 27.959 & .000 & .125 & .144 \\
\hline \multirow{3}{*}{2} & (Constant) & .721 & .059 & & 12.281 & .000 & .605 & .836 \\
\hline & $\begin{array}{l}\text { Duration of } \\
\text { marriage }\end{array}$ & 134 & .005 & .801 & 29.266 & .000 & .125 & .143 \\
\hline & $\begin{array}{l}\text { Religion } \\
\text { (Islam) }\end{array}$ & 2.299 & .326 & .193 & 7.057 & .000 & 1.659 & 2.939 \\
\hline \multirow{4}{*}{3} & (Constant) & .425 & .111 & & 3.814 & .000 & .206 & .643 \\
\hline & $\begin{array}{l}\text { Duration of } \\
\text { marriage }\end{array}$ & .132 & .005 & .793 & 29.161 & .000 & .123 & .141 \\
\hline & $\begin{array}{l}\text { Religion } \\
\text { (Islam) }\end{array}$ & 2.384 & .324 & .200 & 7.368 & .000 & 1.748 & 3.020 \\
\hline & $\begin{array}{l}\text { Couple's } \\
\text { desire no. of } \\
\text { son }\end{array}$ & .151 & .049 & .085 & 3.119 & .002 & .056 & .247 \\
\hline \multirow{5}{*}{4} & (Constant) & .873 & .213 & & 4.093 & .000 & .454 & 1.293 \\
\hline & $\begin{array}{l}\text { Duration of } \\
\text { marriage }\end{array}$ & .132 & .005 & .789 & 29.127 & .000 & .123 & .140 \\
\hline & $\begin{array}{l}\text { Religion } \\
\text { (Islam) }\end{array}$ & 2.406 & .322 & .202 & 7.479 & .000 & 1.774 & 3.039 \\
\hline & $\begin{array}{l}\text { Couple's } \\
\text { desire no. of } \\
\text { son }\end{array}$ & .152 & .048 & .085 & 3.141 & .002 & .057 & .246 \\
\hline & $\begin{array}{l}\text { Use of } \\
\text { contraceptive } \\
\text { s }\end{array}$ & -.463 & . 188 & -.066 & -2.459 & .014 & -.832 & -.093 \\
\hline
\end{tabular}

Table-3: Adjusted Odds Ratios of variables on $3^{\text {rd }}$ birth transition

\begin{tabular}{|c|c|c|c|c|c|c|c|}
\hline \multirow{2}{*}{ Variable } & \multirow[b]{2}{*}{$\beta$} & \multirow[b]{2}{*}{ S.E. } & \multirow[b]{2}{*}{ Wald } & \multirow{2}{*}{$\begin{array}{l}P \text { - } \\
\text { value }\end{array}$} & \multirow[b]{2}{*}{$e^{\beta}$} & \multicolumn{2}{|c|}{ 95\% CI for $e^{\beta}$} \\
\hline & & & & & & Lower & Upper \\
\hline Religion (Hindu) & .013 & .358 & .001 & .972 & 1.013 & .502 & 2.042 \\
\hline Religion (Islam) & -.129 & 1.025 & .016 & .900 & .879 & .118 & 6.554 \\
\hline Fertility of generation-1 & .023 & .055 & .180 & .671 & 1.024 & .919 & 1.140 \\
\hline Fertility of generation-2 & -.138 & .055 & 6.363 & .012 & .871 & .782 & .970 \\
\hline Fertility of generation-3 & .171 & .067 & 6.561 & .010 & 1.186 & 1.041 & 1.352 \\
\hline
\end{tabular}


Fertility Transition Through Four Generations And Determinants Of Third Birth In Manipur

\begin{tabular}{|l|l|l|l|l|l|l|l|}
\hline Education of husband & .025 & .043 & .341 & .559 & 1.025 & .943 & 1.115 \\
\hline Education of wife & -.143 & .031 & 21.311 & .000 & .867 & .816 & .921 \\
\hline Age at marriage of wife & -.122 & .042 & 8.628 & .003 & .885 & .815 & .960 \\
\hline Age at marriage of husband & -.025 & .038 & .439 & .508 & .975 & .905 & 1.051 \\
\hline Couple's desire no. of son & .154 & .156 & .975 & .323 & 1.167 & .859 & 1.586 \\
\hline $\begin{array}{l}\text { Employment status of } \\
\text { husband }\end{array}$ & .570 & .268 & 4.546 & .033 & 1.769 & 1.047 & 2.989 \\
\hline Employment status of wife & -.333 & .676 & .242 & .623 & .717 & .191 & 2.697 \\
\hline Use of contraceptives & -1.525 & .594 & 6.595 & .010 & .218 & .068 & .697 \\
\hline Constant & 4.448 & 1.180 & 14.219 & .000 & 85.442 & & \\
\hline
\end{tabular}

Table-3a: Stepwise Odds Ratios of variables on $3^{\text {rd }}$ birth transition

\begin{tabular}{|c|c|c|c|c|c|c|c|c|}
\hline \multirow[t]{2}{*}{ Step } & \multirow[t]{2}{*}{ Variable } & \multirow[b]{2}{*}{$\beta$} & \multirow[b]{2}{*}{ S.E. } & \multirow[b]{2}{*}{ Wald } & \multirow[b]{2}{*}{$\begin{array}{l}\text { P- } \\
\text { value }\end{array}$} & \multirow[b]{2}{*}{$e^{\beta}$} & \multicolumn{2}{|c|}{$\begin{array}{lll}95 \% & \text { CI for } \\
e^{\beta} & & \end{array}$} \\
\hline & & & & & & & $\begin{array}{l}\text { Lowe } \\
\mathbf{r}\end{array}$ & Upper \\
\hline \multirow[t]{2}{*}{1} & Education of wife & -.158 & .024 & 42.757 & .000 & .854 & .814 & .895 \\
\hline & Constant & .789 & .246 & 10.251 & .001 & 2.201 & & \\
\hline \multirow{3}{*}{2} & Education of wife & -.123 & .026 & 22.556 & .000 & .884 & .840 & .930 \\
\hline & Age at marriage of wife & -.134 & .029 & 21.780 & .000 & .875 & .827 & .925 \\
\hline & Constant & 3.539 & .645 & 30.109 & .000 & 34.427 & & \\
\hline \multirow{4}{*}{3} & Education of wife & -.124 & .026 & 22.155 & .000 & .884 & .839 & .930 \\
\hline & Age at marriage of wife & -.137 & .029 & 22.101 & .000 & .872 & .824 & .923 \\
\hline & Use of contraceptives & -1.376 & .565 & 5.945 & .015 & .252 & .083 & .763 \\
\hline & Constant & 4.920 & .889 & 30.633 & .000 & 137.054 & & \\
\hline \multirow{5}{*}{4} & Education of wife & -.138 & .027 & 25.495 & .000 & .871 & .825 & .919 \\
\hline & Age at marriage of wife & -.134 & .029 & 20.999 & .000 & .875 & .826 & .926 \\
\hline & $\begin{array}{lll}\begin{array}{l}\text { Employment status of } \\
\text { husband }\end{array} & \\
\end{array}$ & .582 & .253 & 5.312 & .021 & 1.790 & 1.091 & 2.937 \\
\hline & Use of contraceptives & -1.302 & .562 & 5.363 & .021 & .272 & .090 & .819 \\
\hline & Constant & 4.717 & .892 & 27.977 & .000 & 111.874 & & \\
\hline \multirow{6}{*}{5} & Fertility of generation-2 & -.122 & .053 & 5.249 & .022 & .885 & .797 & .982 \\
\hline & Education of wife & -.142 & .028 & 26.342 & .000 & .867 & .821 & .916 \\
\hline & Age at marriage of wife & -.134 & .029 & 21.183 & .000 & .874 & .826 & .926 \\
\hline & $\begin{array}{l}\text { Employment status of } \\
\text { husband }\end{array}$ & .585 & .255 & 5.263 & .022 & 1.796 & 1.089 & 2.961 \\
\hline & Use of contraceptives & -1.441 & .580 & 6.180 & .013 & .237 & .076 & .737 \\
\hline & Constant & 5.539 & .978 & 32.049 & .000 & 254.385 & & \\
\hline \multirow{7}{*}{6} & Fertility of generation-3 & .158 & .065 & 5.977 & .014 & 1.171 & 1.032 & 1.329 \\
\hline & Fertility of generation- 2 & -.138 & .054 & 6.486 & .011 & .871 & .783 & .969 \\
\hline & Education of wife & -.139 & .028 & 24.348 & .000 & .870 & .823 & .920 \\
\hline & Age at marriage of wife & -.142 & .030 & 22.665 & .000 & .868 & .819 & .920 \\
\hline & $\begin{array}{l}\begin{array}{l}\text { Employment status of } \\
\text { husband }\end{array} \\
\end{array}$ & .631 & .258 & 5.979 & .014 & 1.879 & 1.133 & 3.116 \\
\hline & Use of contraceptives & -1.466 & .576 & 6.483 & .011 & .231 & .075 & .714 \\
\hline & Constant & 4.906 & 1.004 & 23.886 & .000 & 135.083 & & \\
\hline
\end{tabular}

